\title{
Efficacy Study of Garlic Leaf on Feed Utilization and Growth Performances of Rabbits
}

\author{
Md Kauser Hossian ${ }^{1}$, Md Younus Ali ${ }^{2 *}$, Md Kamruzzaman $^{1}$ and Md \\ Jasimuddin Khan ${ }^{1}$ \\ ${ }^{1}$ Department of Animal Nutrition, Bangladesh Agricultural University, Mymensingh, \\ Bangladesh \\ ${ }^{2}$ Department of Animal Breeding and Genetics, Bangladesh Agricultural University, \\ Mymensingh, Bangladesh \\ *Corresponding Author: Md Younus Ali, Department of Animal Breeding and \\ Genetics, Bangladesh Agricultural University, Mymensingh, Bangladesh.
}

Received: December 18, 2019

Published: January 03, 2020

(c) All rights are reserved by Md Younus

Ali., et al.

DOI: 10.31080/ASNH.2020.04.0597

\begin{abstract}
This experiment was conducted to investigate the effects of garlic leaf supplementation on the growth performance, nutrients digestibility, and carcass characteristics of rabbits. Fifteen male New Zealand White growing rabbits were purchased and randomly allocated into three treatment groups having five rabbits in each group. Group $\mathrm{T}_{0}$ considered as control and was fed diet without having any garlic supplementation; whereas treatment group $\mathrm{T}_{1}$ and $\mathrm{T}_{2}$ were fed adding $5 \%$ and $10 \%$ garlic leaf of their body weight along with green grass. The rabbits in $\mathrm{T}_{1}$ group gained the highest live weight (802.2g) among the other groups. There was no significant difference among the treatment groups for the digestibility of nutrients but these values were numerically higher in $\mathrm{T}_{1}$ group than other groups ( $p>0.05)$. At the end of the experiment, the rabbits were slaughtered and dressed to estimate the different carcasses parameters and found less fat content in the meat of $\mathrm{T}_{1}$ group but while there were no significant differences for carcass yield, dressing percentage and protein content of meat among the treatment groups ( $p>0.05$ ). Therefore, it may be concluded that the garlic leaf at $5 \%$ of the rabbit body weight along with green grass might be used for rabbit feeding in Bangladesh and may require futher study along with different inclusion level of garlic leaves to draw a better suggestion in this regards.
\end{abstract}

Keywords: Rabbit; Garlic Leaf; Growth Performance; Carcass Quality

\section{Introduction}

Acute crisis of human food particularly animal protein is the major problem of Bangladesh. Here, meat is produced from different conventional sources like poultry, cattle, sheep, and goat which are quite insufficient to meet up the growing demand of animal protein in spite of the high density of livestock population. Protein deficiency has been taken as the major contributory factor in malnutrition. Per capita meat consumption in Bangladesh is only 106.21g per day per head against the standard requirement of $120 \mathrm{~g}$ per day per head [1]. It is therefore, important to explore some alternative sources of meat to minimize the deficiency of protein. So, small herbivorous and unconventional species of livestock like "rabbit" would be an integral part of the agricultural farming system that may play a crucial role in nutrition, income generation and self-employment in Bangladesh. Rabbits are small in size, shorter gestation period (28-32 days), early sexual maturity and have the ability to rebreed shortly after kindling [2] and involve little financial investment where women and children can easily accomplish its husbandry at home. Rabbits are able to thrive on non-conventional feedstuffs with their utilization of large forage diets limited as a result of post gastric fiber digestion in the caecum [3]. Furthermore, rabbits do not compete with humans for grain as strongly as chickens [4]. Rabbit meat is considered as of high quality meat that contains low in fat and cholesterol $[5,6]$. Rabbit is rear and widely use as a model animal for different laboratory works. But farming of rabbit as a means of alternative nutritious diet and source of rural family income has not been yet made popular in Bangladesh [2] and little information is available on feeding garlic leaf on growth performance, nutrients utilization, and carcass quality. Therefore, this present work was undertaken to see the effect of garlic leaf on the growth performance and carcass quality of the rabbit.

\section{Materials and Methods}

Site of the experiment

The experiment was conducted at Shahjalal Animal Nutrition Field Laboratory under the Department of Animal Nutrition, Bangladesh Agricultural University, Mymensingh. 


\section{Management of the research activities}

Cages were prepared before starting the experiment and garlic leaves were cultivated for the feeding of rabbits. The Rabbits were collected from Muktaghasa and divided into three groups with five replications in a completely randomized design. There were three dietary treatments containing $0 \%, 5 \%$, and $10 \%$ garlic leaf of their body weight along with green grass designated as $\mathrm{T}_{0^{\prime}}, \mathrm{T}_{1}$, and $\mathrm{T}_{2^{\prime}}$ respectively. The concentrate mixture was prepared according to NRC [7] recommendation by using locally available feed ingredients. Before the commencement of the study, the rabbits were kept for 7 days to adopt with the experimental feeds. The required quantities of feed (concentrate and green grass) were supplied twice in a day (once in the morning at 8.00 am and afternoon at $4.00 \mathrm{pm}$ ). Clean and fresh water was made available for rabbits at all times. The live weight of the rabbits was measured (MEGA, Model-905, capacity $15 \mathrm{~kg}$, LED/LCD double display) weekly and recorded in the data sheet and calculated live weight gain $(\mathrm{g} / \mathrm{d})$ by subtracting the initial weight from the final weight.

\section{Digestibility trial}

During the last week of the experimental period, a conventional digestibility trial was conducted for 7 days. Every day the leftover feeds were recorded and deducted from the feed supplied to determine feed intake of the experimental rabbit. Every day in the morning faeces of each rabbit were collected in a specific polythene bag (Zipper Bags, Zip Lock, Double Layers, 8x12cm) weighed and then faeces were stored in the refrigerator (Samsung, Capacity 36 liter, Weight $60 \mathrm{~kg}$ ). After finishing the digestibility trial fresh faces samples of each experimental rabbit were kept for the determination of a dry matter of the fresh faces sample. Then the rest of each faeces samples were dried in the sun and grinned by the grinding machine (LG, Model CT293, Speed $5000 \mathrm{rpm}$ ). The grinned samples were stored in the specific polythene bag for proximate analysis.

Carcass quality measurement

At the end of the experimental period rabbits were weighed and slaughtered for the measurement of carcass yield, dressing percentage, and also for meat composition.

\section{Statistical analysis}

Statistical analyses were performed using Statistical Analysis System (SAS) software version 9.1.3 [8]. $\alpha=0.05$.

\section{Results and Discussion}

\section{Growth performance of rabbits}

Data on growth performances of rabbits at different levels $(0 \%$, $5 \%$ and $10 \%$ of their body weight) of garlic leaf with green grass is shown in Table 1. The initial average live weights of the rabbits were 386.8, 383.8, and 361.2g for the diet of $\mathrm{T}_{0}, \mathrm{~T}_{1}$ and $\mathrm{T}_{2}$ respectively. After 28 days of the experimental period, the average final live weights of rabbits for different treatments of the diet of $\mathrm{T}_{0}$,
$\mathrm{T}_{1}$ and $\mathrm{T}_{2}$ were $802.2,808.0$ and $767.8 \mathrm{~g}$ respectively. Results indicate that the live weight changes of rabbit among different groups did not differ significantly ( $p>0.05$ ). The average daily live weight gain was $14.83 \mathrm{~g}\left(\mathrm{~T}_{0}\right), 15.15 \mathrm{~g}\left(\mathrm{~T}_{1}\right)$ and $14.52 \mathrm{~g}\left(\mathrm{~T}_{2}\right)$ among the treatment groups. No significant variation $(p>0.05)$ was found among the three dietary treatment groups for the supplementation of garlic leaf with green grass but T1 treatment group had the higher daily live weight gain which may be due to increased amounts of protein availability at the cellular level for deposition in the body tissues. This result was similar to the finding of Pourali., et al. [9] who showed that allicin in garlic promotes the performance of the intestinal flora by improving digestion and utilization of energy, leading to improved growth. Ademola., et al. [10] who reported an increased weight gain of rabbits and broilers, fed garlic supplemented diets.

\begin{tabular}{|l|c|c|c|c|c|}
\hline \multirow{2}{*}{ Parameters } & \multicolumn{3}{|c|}{ Treatments } & \multirow{2}{*}{ P-value } & \multirow{2}{*}{ Comment } \\
\cline { 2 - 5 } & $\mathbf{T}_{\mathbf{0}}$ & $\mathbf{T}_{\mathbf{1}}$ & $\mathbf{T}_{\mathbf{2}}$ & & \\
\hline $\begin{array}{l}\text { Initial body } \\
\text { weight (g) }\end{array}$ & 386.8 & 383.8 & 361.2 & 0.73 & NS \\
\hline $\begin{array}{l}\text { Final body } \\
\text { weight (g) }\end{array}$ & 802.2 & 808.0 & 767.8 & 0.67 & NS \\
\hline $\begin{array}{l}\text { Live weight } \\
\text { gain (g/d) }\end{array}$ & 14.83 & 15.15 & 14.52 & 0.92 & NS \\
\hline
\end{tabular}

Table 1: Effects of garlic leaf on growth performance of rabbits.

$$
\text { NS: Non-significant. }
$$

\section{Nutrients digestibility and nutritive values}

Table 2 showed that the digestibility of nutrient components of different diets. The finding showed that supplementation of garlic leaf did not affect the digestibility of DM, CP, CF, OM, EE, and NFE and no significant variation ( $\mathrm{p}>0.05)$ was found among the three dietary treatment groups. But the digestibility of $\mathrm{CP}$ in $\mathrm{T}_{1}$ diet was numerically higher. The finding of $\mathrm{CP}$ and $\mathrm{CF}$ digestibility disagrees with Patra., et al. [11] and Shehata., et al. [12] who reported that $\mathrm{CP}$ and $\mathrm{CF}$ digestibility were significantly $(\mathrm{p}<0.05)$ improved by the supplementation of garlic with different levels. The results showed that supplementation of garlic leaf had no effect on digestible crude protein, digestible crude fiber, digestible ether extract, digestible nitrogen-free extract, and digestible organic matter and no significant variation $(p>0.05)$ was found among the three dietary treatment groups. But digestible crude protein and total digestible nutrient were higher in T1 diet. These findings were similar to Patra., et al. [11] and Shehata., et al. [12] who stated that DCP and TDN significantly $(\mathrm{p}<0.05)$ improved by the supplementation of garlic with different levels.

\section{Carcass characteristics}

Measurement of different carcass characteristics of the rabbit of the three treatment groups was shown in Table 3. The carcass weight were 382, 365.4 and 362.6g for dietary treatment T0, T1 


\begin{tabular}{|l|c|c|c|c|c|}
\hline \multicolumn{1}{|c|}{ Parameters } & \multicolumn{3}{|c|}{ Treatments } & \multirow{2}{*}{ P value } & Comments \\
\cline { 1 - 4 } $\begin{array}{c}\text { Digestibility } \\
\text { (\%) }\end{array}$ & $\mathbf{T}_{\mathbf{0}}$ & $\mathbf{T}_{\mathbf{1}}$ & $\mathbf{T}_{\mathbf{2}}$ & & \\
\hline DM & 80.33 & 78.45 & 79.39 & 0.22 & NS \\
\hline OM & 85.90 & 84.84 & 85.34 & 0.43 & NS \\
\hline CP & 76.09 & 76.86 & 75.85 & 0.12 & NS \\
\hline CF & 80.65 & 80.45 & 80.35 & 0.95 & NS \\
\hline EE & 90.42 & 90.82 & 91.56 & 0.20 & NS \\
\hline NFE & 88.56 & 88.04 & 87.85 & 0.36 & NS \\
\hline Nutritive value & \multicolumn{5}{|l}{} \\
\hline DCP & 10.45 & 11.76 & 10.42 & 0.16 & NS \\
\hline DCF & 5.58 & 6.37 & 5.64 & 0.08 & NS \\
\hline DEE & 3.21 & 3.08 & 3.11 & 0.84 & NS \\
\hline DNFE & 59.48 & 59.13 & 58.88 & 0.35 & NS \\
\hline DOM & 78.70 & 78.38 & 78.18 & 0.88 & NS \\
\hline TDN & 81.94 & 83.38 & 81.17 & 0.07 & NS \\
\hline
\end{tabular}

\begin{tabular}{|l|c|c|c|c|c|}
\hline \multirow{2}{*}{ Parameters } & \multicolumn{3}{|c|}{ Treatments } & \multirow{2}{*}{ P-value } & \multirow{2}{*}{ Comment } \\
\cline { 2 - 5 } & $\mathbf{T}_{\mathbf{0}}$ & $\mathbf{T}_{\mathbf{1}}$ & $\mathbf{T}_{\mathbf{2}}$ & & \\
\hline $\begin{array}{l}\text { Carcass } \\
\text { weight(g) }\end{array}$ & 382.0 & 365.4 & 362.6 & 0.76 & NS \\
\hline $\begin{array}{l}\text { Dressing yield } \\
\text { (\%) }\end{array}$ & 52.50 & 54.47 & 52.15 & 0.17 & NS \\
\hline EE (\%) & 3.73 & 2.79 & 2.92 & 0.06 & NS \\
\hline
\end{tabular}

Table 3: Effects of garlic leaf on carcass characteristics of rabbits.

\section{NS: Non-Significant.}

sizes covering different inclusion level of garlic leaves would be required to draw a better conclusion in this regard.

\section{Conflict of Interest}

The authors declare no conflict of interest.

\section{Bibliography}

1. Department of Livestock Services 2015: Department of Livestock Services, Khamarbari Road, Dhaka (2015).

2. Hassan HE., et al. "Evaluation of body weight and some morphometric traits at various ages in local rabbits of Sudan". Journal of Animal Science Advance 2 (2012): 407-415.

3. Belenguer A., et al. "In vivo and in vitro study of caecal fermentation pattern and methanogenesis in rabbits". 9th World Rabbit Congress Verona, Italy (2008): 535-540.

and $\mathrm{T}_{2}$ respectively and the dressing yield of the rabbits in $\mathrm{T}_{0}, \mathrm{~T}_{1}$, and $\mathrm{T}_{2}$ groups were $52.50,54.47$, and $52.15 \%$ respectively (Table 3 ). There was no significant ( $>0.05$ ) variation among the treatment groups. Results indicate that maximum dressing yield was found in $\mathrm{T}_{1}$ treated group. The results of this present study collaborate with the findings of Dieumou., et al. [13] and Fadlalla., et al. [14]. They reported that garlic powder has no significant effect on broiler dressing percentage. The EE or crude fat content of meat were $3.73 \%, 2.79 \%$ and $2.92 \%$ for the dietary treatments $\mathrm{T}_{0}, \mathrm{~T}_{1}$ and $\mathrm{T}_{2}$ respectively (Table 3 ) and the result indicated that garlic leaf reduced the fat content of meat. The finding was similar to the reports of Vidica., et al. [15] who showed that incorporation of $0.75 \%$ garlic in the diet of broilers reduced drastically the level of cholesterol in the meat. Chowdhury., et al. [16] reported that garlic has a cholesterol-lowering effect in layer chicken only due to the presence of sulfur-containing bioactive compounds in its homogenates.

\section{Conclusion}

In the present study, supplementation of garlic leaf with basal feed improves growth performance, dressing yield, and meat quality of rabbit. Therefore, it can be suggested that adding $5 \%$ garlic leaf of their body weight along with green grass may be effective for rabbit production. However, further study with larger sample

4. Moreki JC. "Commercial rabbit production”. Agrinews Magazine 38 (2007): 2-12.

5. Jones ND. "The developing market for farm bred meat rabbit in Britain”. Animal Production 50 (1990): 66.

6. Handa MC., et al. "Rabbits for meat production". Asian Livestock 20 (1995): 99-100.

7. NRC. "Nutrient requirement of rabbits" (1997).

8. SAS. SAS User's guide. SAS Institute Inc., Cary, North Carolina, USA (2009).

9. Pourali M., et al. "Effect of garlic powder on productive performance and immune response of broiler chickens challenged with Newcastle disease virus". Global Veterinaria 4 (2010): 616-621.

10. Ademola SG., et al. "Growth performance antimicrobial activity of garlic and ginger mixture fed to broiler". Proceedings of the Nigerian Society for Animal Production (2005): 71-74.

11. Patra RC., et al. "Antioxidant effect of $\alpha$ tocopherol, ascorbic acid and L-methionine on lead induced oxidative stress to the liver, kidney and brain in rats". Toxicology 162 (2001): 81-88. 
12. Shehata SA., et al. "Reducing of the dietary toxicity of T- 2 toxin and diacetoxyscripenol (DAS) by garlic in fish". Journal of Agricultural Science Mansoura University 28 (2003): 7169-7182

13. Dieumou FEA., et al. "Effects of ginger (Zingiberofficinale) and garlic (Allium sativum) essential oils on growth performance and gut microbial population of broiler chickens". Livestock Research for Rural Development 21 (2009): 21-24.

14. Fadlalla IMT., et al. "Effect of feeding garlic on the performance and immunity of broilers". Asian Journal of Poultry Science 4 (2010): 182-189.

15. Vidica S., et al. "Effect of garlic (Allium sativum) in fattening chicks". African Journal Agricultural Research 6 (2011): 943948.

16. Chowdhury SR., et al. "Effects of Dietary Garlic on Cholesterol Metabolism in Laying Hens". Journal of Poultry Science 81 (2002): 1856-1862.

\section{Assets from publication with us}

- Prompt Acknowledgement after receiving the article

- Thorough Double blinded peer review

- Rapid Publication

- Issue of Publication Certificate

- High visibility of your Published work

Website: https://www.actascientific.com/

Submit Article: https://www.actascientific.com/submission.php Email us: editor@actascientific.com

Contact us: +919182824667 